
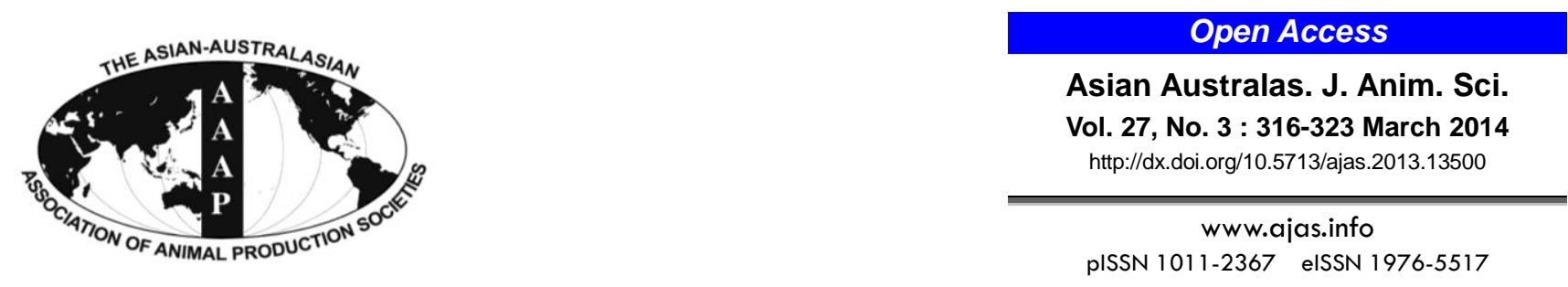

\title{
Association between Motilin Receptor Gene Haplotypes and Growth Traits in Japanese Hinai-dori Crossbred Chickens
}

\author{
Hideaki Takahashi*, Kazuhiro Rikimaru ${ }^{1}$, Megumi Komatsu ${ }^{1}$, Yoshinobu Uemoto ${ }^{2}$, and Keiichi Suzuki ${ }^{3}$ \\ National Institute of Livestock and Grassland Science, Tsukuba, Ibaraki 305-0901, Japan
}

\begin{abstract}
We previously identified quantitative trait loci (QTL) for body weight and average daily gain in a common region between ADL0198 (chr 1: $171.7 \mathrm{Mb}$ ) and ABR0287 (chr 1: $173.4 \mathrm{Mb}$ ) on chicken chromosome 1 in an $\mathrm{F}_{2}$ resource population produced by crossing low- and high-growth lines of the Hinai-dori breed. Motilin receptor (MLNR) is a candidate gene affecting growth traits in the region. In this study, we genotyped polymorphisms of the $M L N R$ gene and investigated its association with growth traits in a Hinaidori $\mathrm{F}_{2}$ intercross population. All the exons of the $M L N R$ gene in the parental population were subjected to PCR amplification, nucleotide sequenced and haplotypes identified. To distinguish resultant diplotype individuals in the $\mathrm{F}_{2}$ population, a mismatch amplification mutation assay was performed. Three haplotypes (Haplotypes 1-3) were accordingly identified. Six genotypes produced by the combination of three haplotypes (Haplotype 1,2, and 3) were examined in order to identify associations between $M L N R$ haplotypes and growth traits. The data showed that Haplotype 1 was superior to Haplotype 2 and 3 in body weight at 10 and 14 weeks of age, average daily gain between 4 and 10 weeks, 10 and 14 weeks, and 0 and 14 weeks of age in female in $F_{2}$ females. It was concluded that $M L N R$ is a useful marker of growth traits and could be used to develop strategies for improving growth traits in the Hinai-dori breed. (Key Words: Chicken, Hinai-dori, Growth, Marker Gene, Motilin Receptor)
\end{abstract}

\section{INTRODUCTION}

The Hinai-dori is a slow-growing breed of chicken native to Akita Prefecture, in northern Honshu Island, Japan. Although Hinai-dori meat has a characteristic taste and the breed has been used for a long time, it has decreased in numbers in recent times owing to the introduction of exotic breeds, and for a while was at risk of extinction. The Hinaidori breed has been conserved by hobbyists who belong to the Preservation Society (PS) of the Hinai-dori Breed and is now mainly used for exhibition purposes. For effective use of the breed, selection experiments have been performed at

\footnotetext{
* Corresponding Author: Takahashi Hideaki. Tel: +81-29-8388623, Fax: +81-29-838-8606, E-mail: naoe@affrc.go.jp

${ }^{1}$ Akita Prefectural Livestock Experiment Station, Daisen 0191701, Japan.

${ }^{2}$ National Livestock Breeding Center, Nishigo, Fukushima 961 8511, Japan.

${ }^{3}$ Graduate School of Agricultural Science, Tohoku University, Sendai 981-8555, Japan.

Submitted Aug. 13, 2013; Accepted Oct. 10, 2013; Revised Nov. 16, 2013
}

the Akita Prefectural Livestock Experiment Station (LES) since 1973 when fertilized eggs were introduced to LES from PS with a view towards increasing growth performance (Rikimaru et al., 2013). At present, the sexaveraged body weight of LES line at 14 weeks of age is approximately $0.8 \mathrm{~kg}$ heavier than that of PS line (Rikimaru et al., 2013). $F_{1}$ chickens produced by crossing the improved LES Hinai-dori sires with Rhode Island Red dams have been commercialized as the Hinai-jidori chicken, which is one of the most popular high-quality chickens on the Japanese market (Rikimaru et al., 2007).

The identification and utilization of potential candidate genes for quantitative trait loci (QTL) with significant effects on economically important traits is becoming increasingly important in animal breeding programs. There are currently two main strategies for detecting QTLs: genome scans based on linkage mapping in a cross population and association tests using candidate genes (Andersson, 2001). In the past decade, QTL mapping for chicken growth traits such as body weight has been widely studied (Abasht et al., 2006; Hu et al., 2007). Moreover, 
there have been numerous association studies investigating the relationship between growth traits and candidate genes, including pre-B-cell colony enhancing factor I (PBEFI) (Han et al., 2011), high mobility group AT-hook 2 (HMGA2) (Song et al., 2011), insulin-like growth factor I (IGF1) (Zhou et al., 2005), pituitary-specific positive transcription factor 1 (PITl) (Nie et al., 2008), and thyroid hormone responsive spot $14 \alpha$ (THRSP) (Cao et al., 2007) on chromosome 1; insulin-like growth factor binding protein (IGFBP) 1 and 3 (Qu et al., 2009) on chromosome 2; ornithine decarboxylase (ODC) (Uemoto et al., 2011) on chromosome 3; cholecystokinin type A receptor (CCKAR) (Rikimaru et al., 2012) on chromosome 4; calpain 3 (Zhang et al., 2009) on chromosome 5; IGFBP 2 (Lei et al., 2005; Li et al., 2006; Leng et al., 2009) on chromosome 7; growth hormone secretagogue receptor (GHSR) (Fang et al., 2010) on chromosome 9; and insulin-like growth factor 1 receptor (IGFIR) (Lei et al., 2008) on chromosome 10.

The LES line was developed from PS chickens: hence, these individuals possessed genes that influence growth traits. To identify QTLs associated with growth traits in the Hinai-dori breed, an $\mathrm{F}_{2}$ resource population produced by crossing low- and high-growth lines of the breed was analyzed. A significant QTL for body weight at 10 and 14 weeks of age and average daily gain between 4 and 10 weeks and between 10 and 14 weeks of age were accordingly mapped in a common region between $A D L 0198$ (chr 1: $171.7 \mathrm{Mb}$ ) and $A B R 0287$ (chr 1: $173.4 \mathrm{Mb}$ ) on chromosome 1 (Rikimaru et al., 2011). Thus, the abovementioned genes, e.g., IGFBP 1-3, ODC, CCKAR, GHSR, and $I G F 1 R$, are not objects of our interest, since they are not located on chromosome 1. Moreover, PBEF1 (chr 1: 15.2 Mb), HMGA2 (chr 1: 36.1 Mb), IGF1 (chr 1: $57.3 \mathrm{Mb}$ ), PIT1 (chr 1: $96.2 \mathrm{Mb})$, THRSP (chr 1: $197.8 \mathrm{Mb}$ ) are not located between ADL0198 and ABR0287.

Of all the candidate genes for growth traits on chromosome 1, we herein focused our investigation on the motilin receptor $(M L N R$, chr 1: $173.4 \mathrm{Mb})$ because it was located just under the QTL peak adjacent to ABR0287 on chromosome 1 , and motilin is a key regulatory hormones for appetite (Garthwaite, 1985; Rosenfeld and Garthwaite, 1987), and thus $M L N R$ is a positional and functional candidate gene. Our main objective in this study was to analyze polymorphism of the MLNR gene and test its association with growth traits in Hinai-dori $\mathrm{F}_{2}$ crossbreds.

\section{MATERIALS AND METHODS}

\section{Resource population}

PS and LES chickens of the Hinai-dori are shown in Figure 1. $F_{1}$ chickens were produced by crossing three cocks from a low-growth line (obtained from PS) with nine hens from a high-growth line (obtained from LES). In this

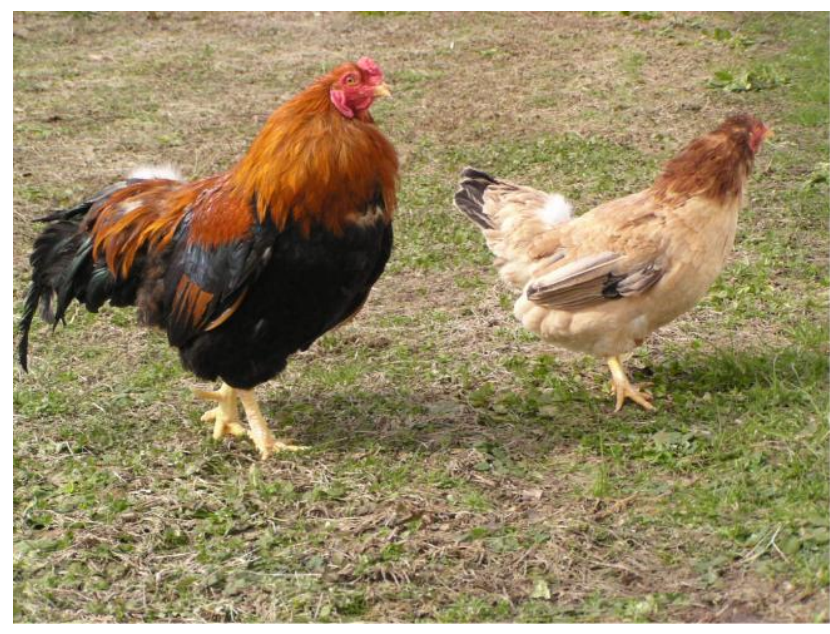

(A)

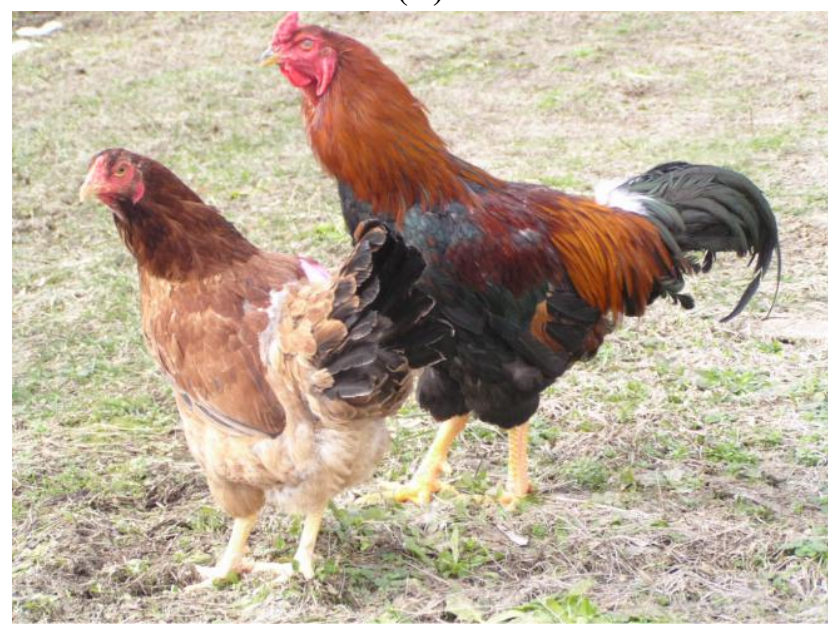

(B)

Figure 1. Hinai-dori. (A) Hinai-dori chickens of the Preservation Society (PS) line. Left, male; right, female. (B) Hinai-dori chickens of the Akita Prefectural Livestock Experiment Station (LES) line. Left, female; right, male.

cross, one to three hens were randomly selected to mate with each male. The $\mathrm{F}_{2}$ individuals were produced by fullsib mating of $17 \mathrm{~F}_{1}$ cocks and $60 \mathrm{~F}_{1}$ hens. We accordingly obtained $418 \mathrm{~F}_{2}$ individuals comprising 206 cocks and 212 hens. The $F_{2}$ chickens were hatched on the same day, raised in the same chicken house, and fed the same diet ad libitum for the duration of the experiment. All animals received humane care as outlined in the Guidelines for Proper Conduct of Animal Experiments, Science Council of Japan (Science Council of Japan, 2006).

\section{Traits}

Body weight was measured at day 0 (BW $0 \mathrm{~d}$ ), 4 weeks (BW 4 wk), 10 weeks (BW $10 \mathrm{wk}$ ), and 14 weeks (BW 14 wk) of age. Average daily gain between 0 and 4 weeks of age (ADG 0-4 wk), between 4 and 10 weeks of age (ADG 4-10 wk), between 10 and 14 weeks of age (ADG 10-14 wk), and 0 and 14 weeks of age (ADG 0-14 wk) was 
Table 1. Polymerase chain reaction primers for the amplification of the 2 exons in the gene encoding the motilin receptor

\begin{tabular}{|c|c|c|c|c|c|c|}
\hline Exon & Set & Forward primer $\left(5^{\prime} \rightarrow 3^{\prime}\right)$ & Reverse primer $\left(5^{\prime} \rightarrow 3^{\prime}\right)$ & $\begin{array}{l}\text { Product } \\
\text { (bp) }\end{array}$ & $\begin{array}{c}\text { Denaturizing } \\
\text { temp. }\left({ }^{\circ} \mathrm{C}\right)\end{array}$ & $\begin{array}{l}\text { Annealing } \\
\text { temp. }\left({ }^{\circ} \mathrm{C}\right)\end{array}$ \\
\hline 1 & 1 & TCTTTTTCGTCCTTCGTTCCTT & CTGAAGTCGGTGCGGTTGT & 704 & 99.5 & 64.0 \\
\hline 1 & 2 & GTCCGACCTGCTCATCCTGCT & CTCATCCGTCTCACCTCCCCTT & 736 & 98.0 & 60.0 \\
\hline 2 & 1 & GGGGAGACACCCAAGGTCAGGC & CCAAGCATTTCAGCACACAAAGAGT & 644 & 94.0 & 62.0 \\
\hline 2 & 2 & CCAGGACCTACACAGAGACCAG & TACAGGGTTGGAGTTAGATGGC & 898 & 94.0 & 62.0 \\
\hline
\end{tabular}

calculated from BW at each week of age.

\section{Identification of MLNR haplotypes}

A draft sequence of the chicken genome (May 2006 assembly), available on the University of California, Santa Cruz (UCSC) Genome Browser (2004) and the Ensembl Genome Browser (2004), was used in this study. The nucleotide sequences of the two exons of $M L N R$ in the parent individuals were determined by polymerase chain reaction (PCR) amplification followed by direct sequencing to determine nucleotide variance of the gene in the resource family. Each genomic DNA of the resource family was purified using a SepaGene kit (EIDIA, Tokyo, Japan). Four PCR primers were designed to separately amplify the two exons of MLNR and the PCRs were performed (Table 1). For the PCRs, we used $15-\mu \mathrm{L}$ reaction volumes containing the following: 10 pmol of each primer for each marker, 200 $\mu \mathrm{M}$ of each deoxyribonucleotide triphosphate (dNTP), 1.2 $\mathrm{mM}$ magnesium sulfate $\left(\mathrm{MgSO}_{4}\right), 0.5$ units of KOD-plus polymerase (Toyobo, Tokyo, Japan), 1× reaction buffer provided by the manufacturer, and $10 \mathrm{ng}$ genomic DNA. Reactions were performed in a 96-well plate in an iCycler Thermal Cycler (Bio-Rad Laboratories, Hercules, CA, USA) using the following conditions: initial denaturation at $94^{\circ} \mathrm{C}$ for $2 \mathrm{~min} ; 30$ cycles at $x^{\circ} \mathrm{C}$ ( $x$ was the denaturizing temperature shown in Table 1) for $15 \mathrm{~s}$, at $y^{\circ} \mathrm{C}$ ( $y$ was the annealing temperature shown in Table 1) for $30 \mathrm{~s}$, at $68^{\circ} \mathrm{C}$ for $30 \mathrm{~s}$; and a final elongation at $68^{\circ} \mathrm{C}$ for $4 \mathrm{~min} 30 \mathrm{~s}$. The PCR products were purified using High Pure 96 UF Cleanup Plates (Roche Diagnostics GmbH, Mannheim, Germany) and subjected to cycle sequencing using a BigDye Terminator Cycle Sequencing FS Ready Reaction kit (Perkin-Elmer Applied Biosystems, Foster City, CA, USA) and the same primers as used for the PCR amplification. Sequencing was performed in both directions and each sequencing product was run in an ABI 3130 Genetic Analyzer (Perkin-Elmer Applied Biosystems). The $M L N R$ gene haplotypes in the $\mathrm{F}_{2}$ intercross population were then identified.

\section{Statistical analyses}

A mixed-inheritance animal model was used to evaluate the effects of haplotypes on traits. The ld_fix option of the Qxpak software (Pérez-Enciso and Misztal, 2004) was used for the MLNR haplotypes. For statistical models, the additive effect of each allele and the sex effect were used as fixed effects. In this analysis, the infinitesimal genetic effect was included and treated as a random effect with covariance matrix $\mathbf{A} \sigma_{u}^{2}$ (where $\mathrm{A}$ is the numerator relationship matrix). Likelihood ratio tests were performed by not including the additive effects in the model, and nominal pvalues were obtained by assuming a $x^{2}$ distribution of the likelihood ratio test.

Percentage of haplotype variance explained by the model was calculated as

Variance percentage

$=100 \times($ R_variance - F_variance $) /$ R_variance

where R_variance is the residual and polygenic variances from the reduced model, omitting haplotype effect but including sex and polygenic effects, and F_variance is the residual variance from the full model, including haplotype, sex, and polygenic effects.

\section{RESULTS}

On sequencing of the $M L N R$ gene, we found GGGGC insertion polymorphisms located $54 \mathrm{bp}$ upstream of the 5'untranslated region and the sequenced region differed by 6 single nucleotide polymorphisms (SNPs) from the corresponding region in the draft sequence of the chicken genome. Resultantly, three MLNR haplotypes (Haplotypes 1-3) were identified in the parent individuals (Table 2). The nucleotide sequences of the three haplotypes have been

Table 2. Genotypes of parent individuals of the $\mathrm{F}_{2}$ populations

\begin{tabular}{lcc}
\hline Individuals & No. & Genotype \\
\hline Parent male & 1 & $2 / 2$ \\
& 2 & $2 / 2$ \\
Parent female & 3 & $2 / 3$ \\
& 1 & $1 / 2$ \\
& 2 & $1 / 2$ \\
& 3 & $2 / 2$ \\
& 4 & $2 / 2$ \\
& 5 & $2 / 2$ \\
& 6 & $1 / 2$ \\
& 7 & $1 / 2$ \\
& 8 & $2 / 2$ \\
\hline
\end{tabular}


Table 3 Polymerase chain reaction (PCR) primers for the mismatch amplification mutation assay (MAMA)

\begin{tabular}{|c|c|c|c|c|c|c|}
\hline \multirow{3}{*}{ Primer sets } & \multirow{3}{*}{ Primers $\left(5^{\prime} \rightarrow 3^{\prime}\right)$} & \multirow{3}{*}{$\begin{array}{c}\text { PCR product } \\
\text { (bp) }\end{array}$} & \multirow{3}{*}{$\begin{array}{c}\text { Target position } \\
\text { (AB703068) }\end{array}$} & \multicolumn{3}{|c|}{ PCR amplification } \\
\hline & & & & \multicolumn{3}{|c|}{ Haplotype } \\
\hline & & & & 1 & 2 & 3 \\
\hline \multirow[t]{2}{*}{ MLNR-1008-13 } & CAGCGTCCTCTACGGCTTCA & 217 & g1008. C>T & + & - & + \\
\hline & GCCGGCGGTCCGTGGța & & & & & \\
\hline \multirow[t]{2}{*}{ MLNR-1008-2 } & CAGCGTCCTCTACGGCTTCA & 217 & g1008. C>T & - & + & - \\
\hline & GCCGGCGGTCCGTGGțg & & & & & \\
\hline \multirow[t]{2}{*}{ MLNR-1029-1 } & GCGTCCTCTACGGCTTCATC & 238 & g1029. $A>G$ & + & - & - \\
\hline & AGTCTGTGGAATGGCGCgTc & & & & & \\
\hline \multirow[t]{2}{*}{ MLNR-1029-23 } & GCGTCCTCTACGGCTTCATC & 238 & g1029. $A>G$ & - & + & + \\
\hline & AGTCTGTGGAATGGCGCgTt & & & & & \\
\hline
\end{tabular}

Bases shown in lower case with an underline represent induced mismatches. Bases shown in lower case at the $3^{\prime}$-end represent target single nucleotide polymorphisms (SNPs). The haplotypes that can or cannot be amplified by PCR for each primer set are shown as '+' or '-', respectively. For the PCRs, we used $15-\mu \mathrm{L}$ reaction volumes containing the following: 3 pmol of each primer for each marker, $200 \mu \mathrm{M}$ of each dNTP, 0.5 units of Paq5000DNA Polymerase (Agilent Technologies, La Jolla, CA, USA), $1 \times$ reaction buffer (containing $2 \mathrm{mM} \mathrm{MgCl}$ ) provided by the manufacturer, and $10 \mathrm{ng}$ genomic DNA, Reactions were performed in a 96-well plate in an iCycler Thermal Cycler (Bio-Rad Laboratories, Hercules, CA, USA) using the following conditions: initial denaturation at $95^{\circ} \mathrm{C}$ for $2 \mathrm{~min} ; 30$ cycles at $94^{\circ} \mathrm{C}$ for $30 \mathrm{~s}$, at $62^{\circ} \mathrm{C}$ for $30 \mathrm{~s}$, at $72^{\circ} \mathrm{C}$ for $1 \mathrm{~min}$ (MLNR-1008-13 and -2), or 35 cycles at $94^{\circ} \mathrm{C}$ for $30 \mathrm{~s}$, at $64^{\circ} \mathrm{C}$ for $30 \mathrm{~s}$, at $72^{\circ} \mathrm{C}$ for $1 \mathrm{~min}$ (MLNR-1029-1 and -23); and a final elongation at $72^{\circ} \mathrm{C}$ for 7 min. The PCR products were electrophoresed on a $2.0 \%$ agarose gel with $1 \times$ Tris-acetate EDTA (TAE) buffer and stained with ethidium bromide. The combination of these results enabled us to identify diplotypes in the $\mathrm{F}_{2}$ population.

registered in the DNA data bank of Japan (DDBJ) with the following accession numbers: AB703068, AB703069, and $\mathrm{AB} 703070$. The results indicated that these haplotypes might be segregated and individuals with six different genotypes $(1 / 1, / 2 / 2,3 / 3,1 / 2,1 / 3$, and $2 / 3)$ might appear in the $F_{2}$ population. Therefore, a mismatch amplification mutation assay (MAMA) PCR protocol was developed that detects the 6 genotypes described by Cha et al. (1992). We designed four PCR primers to distinguish MLNR haplotypes and PCR and genotyping were performed as described in Table 3 and Figure 2.

We observed an association between three $M L N R$ haplotypes (Haplotype 1, 2, and 3) and growth traits (Table 4). There was no association between these haplotypes and growth traits in the overall $\mathrm{F}_{2}$ population. When data were

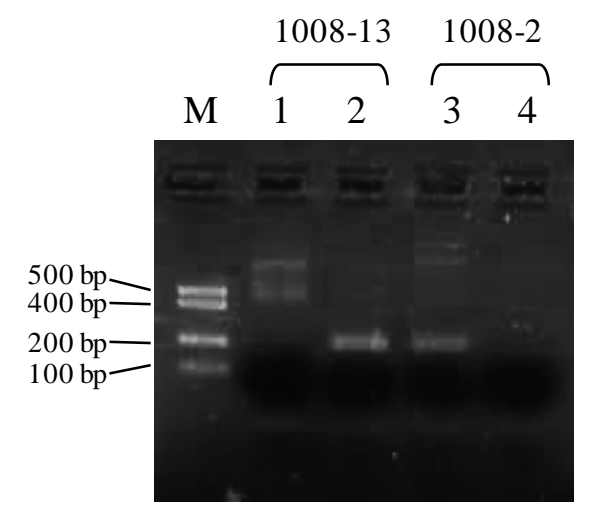

analyzed separately by sex, a significant $(\mathrm{p}<0.05)$ association was found between these haplotypes and BW 10 wk, BW 14 wk, ADG 4-10 wk, ADG 10-14 wk, and ADG $0-14$ wk in $F_{2}$ females, whereas there was no association between these haplotypes and growth traits in $\mathrm{F}_{2}$ males.

\section{DISCUSSION}

Motilin, a 22 amino acid polypeptide first discovered in the mucosa of upper small intestine of the hog (Brown et al., 1971), is predominantly recognized for its prokinetic effects on gastrointestinal motility and emptying (Poitras et al., 1994). Motilin has been identified in many mammals (Bond et al., 1988; Banfield et al., 1992; Xu et al., 2001; Strausberg et al., 2002; Xu e al., 2003; Ohshiro et al., 2008)

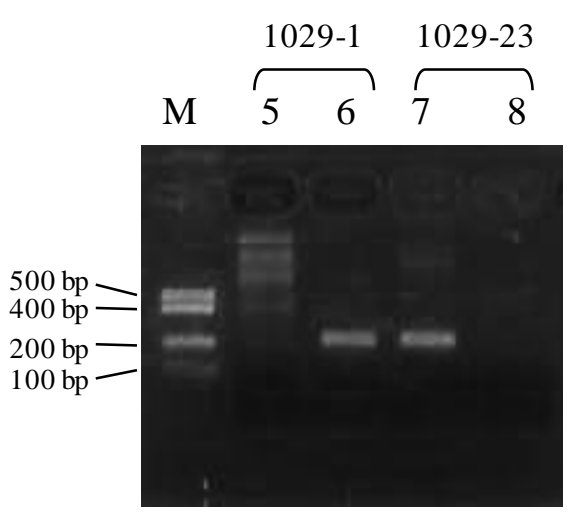

Figure 2. Typical patterns of $2 \%$ agarose gel electrophoresis of MAMA results. (A) MAMA results at the SNP site of AB703068: g.1008 C>T. MLNR-1008-13 and MLNR -1008-2 primer sets were used in lane 1 and 2, and in lane 3 and 4, respectively. Lane M, DNA size marker; lane 1 and 3, patterns of Haplotype 2; lane 2 and 4, patterns of Haplotype 1 and 3. (B) MAMA results at the SNP site of AB703068: g.1029 A>G. MLNR-1029-1 and MLNR-1029-23 primer sets were used in lane 5 and 6, and in lane 7 and 8, respectively. Lane M, DNA size marker; lane 5 and 7; pattern of Haplotype 2 and 3; lane 6 and 8; patterns of Haplotype 1. 
Table 4. Phenotypic values of growth traits and effects of Motilin receptor haplotypes on the traits in the $\mathrm{F}_{2}$ population

\begin{tabular}{|c|c|c|c|c|c|c|c|c|}
\hline \multirow{2}{*}{ Trait } & \multirow{2}{*}{$n$} & Phenotypic values & \multirow{2}{*}{ LRT } & \multirow{2}{*}{$\mathrm{p}$ value } & \multirow{2}{*}{$\begin{array}{c}\text { Haplotype } 1 \\
\text { mean } \pm \text { SE }\end{array}$} & \multirow{2}{*}{$\begin{array}{c}\text { Haplotype } 2 \\
\text { mean } \pm \text { SE } \\
\end{array}$} & \multirow{2}{*}{$\begin{array}{c}\text { Haplotype } 3 \\
\text { mean } \pm \text { SE } \\
\end{array}$} & \multirow{2}{*}{$\begin{array}{c}\text { Variance } \\
(\%)\end{array}$} \\
\hline & & Mean \pm SD & & & & & & \\
\hline \multicolumn{9}{|l|}{ Total } \\
\hline BW 0 d (g) & 418 & $34.4 \pm 2.4$ & 2.7 & 0.255 & - & - & - & - \\
\hline BW 4 wk (g) & $417^{1}$ & $231.1 \pm 38.3$ & 0.2 & 0.888 & - & - & - & - \\
\hline BW 10 wk (g) & 418 & $960.6 \pm 163.5$ & 4.3 & 0.116 & - & - & - & - \\
\hline BW 14 wk (g) & 418 & $1,466.9 \pm 260.7$ & 5.2 & 0.075 & - & - & - & - \\
\hline ADG 0-4 wk (g/d) & $417^{1}$ & $5.2 \pm 1.0$ & 0.3 & 0.856 & - & - & - & - \\
\hline ADG 4-10 wk (g/d) & $417^{1}$ & $17.4 \pm 3.3$ & 5.1 & 0.077 & - & - & - & - \\
\hline ADG 10-14 wk (g/d) & 418 & $18.1 \pm 4.4$ & 3.6 & 0.166 & - & - & - & - \\
\hline ADG 0-14 wk (g/d) & 418 & $14.6 \pm 2.7$ & 5.2 & 0.073 & - & - & - & - \\
\hline \multicolumn{9}{|l|}{ Male } \\
\hline BW 0 d (g) & 206 & $34.6 \pm 2.5$ & 5.0 & 0.041 & - & - & - & - \\
\hline BW 4 wk (g) & $205^{1}$ & $243.6 \pm 38.3$ & 0.3 & 0.797 & - & - & - & - \\
\hline BW 10 wk (g) & 206 & $1,053.4 \pm 144.8$ & 2.2 & 0.536 & - & - & - & - \\
\hline BW 14 wk (g) & 206 & $1,658.8 \pm 199.5$ & 1.5 & 0.670 & - & - & - & - \\
\hline ADG 0-4 wk (g/d) & $205^{1}$ & $5.5 \pm 1.0$ & 0.3 & 0.835 & - & - & - & - \\
\hline ADG 4-10 wk (g/d) & $205^{1}$ & $19.3 \pm 2.9$ & 2.8 & 0.485 & - & - & - & - \\
\hline ADG 10-14wk (g/d) & 206 & $21.6 \pm 2.9$ & 0.1 & 0.970 & - & - & - & - \\
\hline ADG 0-14 wk (g/d) & 206 & $16.6 \pm 2.0$ & 0.8 & 0.672 & - & - & - & - \\
\hline \multicolumn{9}{|l|}{ Female } \\
\hline BW 0 d (g) & 211 & $34.2 \pm 2.3$ & 0.7 & 0.915 & - & - & - & - \\
\hline BW 4 wk (g) & 211 & $219.0 \pm 34.3$ & 3.2 & 0.374 & - & - & - & - \\
\hline BW 10 wk (g) & 211 & $870.8 \pm 125.9$ & 8.6 & $0.021 *$ & $462.9 \pm 20.2$ & $426.1 \pm 15.5$ & $394.4 \pm 23.8$ & 7.5 \\
\hline BW 14 wk (g) & 211 & $1,280.6 \pm 157.4$ & 12.0 & $0.002 *$ & $692.6 \pm 25.6$ & $629.8 \pm 19.5$ & $582.5 \pm 30.3$ & 11.0 \\
\hline ADG 0-4 wk (g/d) & 211 & $4.9 \pm 0.9$ & 3.0 & 0.375 & & & & \\
\hline ADG 4-10wk (g/d) & 211 & $15.5 \pm 2.5$ & 8.9 & $0.041^{*}$ & $8.2 \pm 0.4$ & $7.6 \pm 0.3$ & $7.0 \pm 0.5$ & 5.7 \\
\hline ADG 10-14 wk (g/d) & 211 & $14.6 \pm 2.3$ & 7.5 & $0.007 *$ & $8.2 \pm 0.4$ & $7.3 \pm 0.3$ & $6.7 \pm 0.5$ & 5.5 \\
\hline ADG 0-14 wk (g/d) & 211 & $12.7 \pm 1.6$ & 12.3 & $0.002 *$ & $6.9 \pm 0.3$ & $6.3 \pm 0.2$ & $5.8 \pm 0.3$ & 11.4 \\
\hline
\end{tabular}

BW 0 d, BW 4 wk, BW 10 wk, and BW 14 wk: body weight measured at day 0, 4 weeks, 10 weeks, and 14 weeks of age.

ADG 0-4 wk, ADG 4-10 wk, ADG 10-14 wk, and ADG 0-14 wk: average daily gain between 0 and 4 weeks, between 4 and 10 weeks, between 10 and 14 weeks, and between 0 and 14 weeks.

$\mathrm{SD}=$ Standard deviation. $\mathrm{SE}=$ Standard error. $\mathrm{LRT}=\mathrm{Log}$ likelihood ratio test statistics.

${ }^{1}$ Since BW 4 wk has a missing datum, ADG 0-4 wk and 4-10 wk have missing data. * $\mathrm{p}<0.05$.

and chickens (DeClercq et al., 1996). Motilin binding sites are present in the gastrointestinal tract and central nervous system, along with a G-protein-coupled receptor, GPR38, which has been identified as MLNR (Feighner et al., 1999). Initially, GPR38/MLNR was identified as an orphan receptor belonging to the GHSR family. This family contains receptors for ghrelin (Kojima et al., 1999), neuromedin U (Howard et al., 2000), and neurotensin (Vincent et al., 1999). Of the receptors, the GHSR is most homologous to the MLNR; the chicken forms share 53\% identical amino acids (Yamamoto et al., 2008).

It has been shown that motilin and ghrelin have contractile activities in the gastrointestinal tract and their receptors are presented in the gastrointestinal tract of chickens (Kitazawa et al., 1997; Tanaka et al., 2003), although detail distributions of MLNR and GHSR have not been reported. DeClercq et al. (1996) reported that motilin was most abundant in the mucosa of the colon, followed by the jejunum, duodenum, and ileum; low motilin contents were found in the proventriculus and gizzard. Neglia et al. (2004) reported that the largest numbers of ghrelin-positive cells were located at the base of lobuli of the proventriculus gland, along villi of the intestines and in crypts of the duodenum, while lower numbers of ghrelin-immunostained cells were located in crypts of jejunum and ileum and only few ghrelin-immunostained cells were detected at the base of crypts of the large intestine. Kitazawa et al. (2007) reported that chicken ghrelin caused contraction of chicken gastrointestinal smooth muscles in a region dependent manner (crop>colon>esophagus>proventriculus>jejunum> ileum>duodenum), and chicken motilin caused contraction of chicken gastrointestinal tract in a region dependent manner (duodenum $>$ jejunum $>$ ileum $>$ colon $>$ proventriculus $>$ crop $>$ esophagus). These data suggest that ghrelin mainly 
regulates contractions of the upper (crop, esophagus, and proventriculus) gastrointestinal tract, motilin principally regulates small intestinal motility in chicken. Since it has been reported that motilin can stimulate the GHSR but ghrelin does not activate MLNR in rabbits (Dass et al., 2003) and chickens (Yamamoto et al., 2008), motilin abundantly presented in colon may activate GHSR and lead gastrointestinal mortality in colon. Taken together, these reports suggest that motilin and MLNR play central roles in the regulation of gastrointestinal motility and gastric emptying with ghrelin and GHSR in chicken.

The association between haplotypes and growth traits cannot be explained by the protein sequences, since the SNPs detected in the coding regions of $M L N R$ do not induce missense mutations, and thus MLNR proteins are functionally normal. Therefore, at present, it is unknown whether MLNR haplotypes have any functional significance. The associations detected in this study may be produced by linkage disequilibrium between these haplotypes and another linked gene directly involved in the regulation of these traits. Recently, Zhang et al. (2011) proposed positional candidate genes for growth traits in the same region on chromosome 1, namely, retinoblastoma 1 (RBI) (chr 1: $173.0 \mathrm{Mb}$ ); lysophosphatidic acid receptor 6 (chr 1: $173.0 \mathrm{Mb}$ ); fibronectin type III domain containing $3 A$ (chr 1: $173.3 \mathrm{Mb}) ; M L N R$ (chr 1: $173.4 \mathrm{Mb}$ ); and calcium binding protein 39-like (chr 1: $173.5 \mathrm{Mb})$. Of the genes, Zhang et al. (2011) suggested that two SNPs of RBI gene might be quantitative trait nucleotides for BW; however they have not proposed any hypothetical mechanisms why the SNPs affect BW.

One likely possibility to explain the association between $M L N R$ haplotypes and growth traits is that presence of GGGGC insertion polymorphism in the $5^{\prime}$-upstream region of $M L N R$, corresponding to the predicted $\mathrm{Sp} 1$ binding site, may affect $M L N R$ gene expression. $\mathrm{Sp} 1$ is a transcription factor that plays an important role in many cellular activities such as metabolism, cell growth, differentiation, angiogenesis and apoptosis (Deniaud et al., 2009). Sp1 contains three Cys2His2-type zinc finger motifs and it is generally accepted that its mode of action is mediated mainly by binding to the decanucleotide consensus sequence 5'-(G/T)GGGCGG(G/A)(G/A)(C/T)-3' in doublestranded DNA (dsDNA) (Song et al., 2001). In the predicted Sp1 binding site of $M L N R$ gene, Haplotype 1, 2, and 3 have $(\mathrm{GGGGC})_{3},(\mathrm{GGGGC})_{4}$, and $(\mathrm{GGGGC})_{5}$, respectively, while the draft sequence of the chicken genome has $(\mathrm{GGGGC})_{2}$. Since it was reported that Sp1tandem repeat polymorphisms affect binding capabilities of Sp1 and transcriptional efficiencies (In et al., 1997; Sigurdsson et al., 2008), the repeat polymorphisms in $M L N R$ gene promoter may affect $M N L R$ gene expression. Our data suggest that shorter GGGGC-repeats shows better growth performance rather than longer ones. Therefore, further studies are needed to elucidate the differences in transcriptional and translational efficiencies caused by haplotypes.

It is also unclear the reason that $M L N R$ haplotypes are associated with gender differences in growth traits. Motilin and $M L N R$ genes in mice and rats exist as pseudogenes and are thought to genetically knockdown; however, it is still debated whether or not native MLNR is expressed (He et al., 2010). Recently, Miegueu et al. (2011) demonstrated that motilin stimulates preadipocyte proliferation and differentiation and adipocyte lipid storage in murine 3T3L1 and primary rat adipocytes. Previous reports indicated that acylated and unacylated ghrelin might influence preadipocyte proliferation (Zhang et al., 2004) and could enhance preadipocyte differentiation (Miegueu et al., 2011), thus, motilin may act via GHSR in the murine and rat adipocytes. Zigman (Zigman et al., 2005) reported that female GHSR-null mice were significantly lighter than wild-type controls between 12 and 19 weeks of age, while male GHSR-null and wild-type mice did not differ in body weight at any weeks of age. After 19 weeks of age, female GHSR-null mice had $35.6 \%$ less body fat than wild-type mice. Taken together, these data may imply that MLNR plays a key role in fat deposition and body weight especially in females; however, further studies needed to clarify the reason how MLNR affect fat traits in chicken.

In conclusion, we observed significant associations between MLNR haplotypes and growth traits in an $\mathrm{F}_{2}$ population produced by crossing low- and high-growth lines of the Hinai-dori breed of chicken. Our data suggest that haplotype-assisted selection is a potentially useful approach in the Hinai-dori breed. In the future, the associations between haplotypes and growth traits should be studied in other chicken lines and breeds.

\section{ACKNOWLEDGEMENTS}

This work was financially supported by the Integrated Research Project for Plant, Insect, and Animal Using Genome Technology from the Ministry of Agriculture, Forestry and Fisheries of Japan.

\section{REFERENCES}

Abasht, B., J. C. M. Dekkers, and S. J. Lamont. 2006. Review of quantitative trait loci identified in the chicken. Poult. Sci. 85: 2079-2096.

Andersson, L. 2001. Genetic dissection of phenotypic diversity in farm animals. Nat. Rev. Genet. 2:130-138.

Banfield, D. K., R. T. A. MacGillivray, J. C. Brown, and C. H. S. McIntosh. 1992. The isolation and characterization of rabbit motilin precursor cDNA. Biochim. Biophys. Acta. 1131:341344. 
Bond, C. T., G. Nilaver, B. Godfrey, E. A. Zimmerman, and J. P. Adelman. 1988. Characterization of complementary deoxyribonucleic acid for precursor of porcine motilin. Mol. Endocrinol. 2:175-180.

Brown, J. C., V. Mutt, and J. R. Dryburgh. 1971. The further purification of motilin, a gastric motor activity stimulating polypeptide from the mucosa of the small intestine of hogs. Can. J. Physiol. Pharmacol. 49:399-405.

Cao, Z. P., S. Z. Wang, Q. G. Wang, Y. X. Wang, and H. Li. 2007. Association of spot $14 \alpha$ gene polymorphisms with body weight in the chicken. Poult. Sci. 86:1873-1880.

Cha, R. S., H. Zarbl, P. Keohavong, and W. G. Thilly. 1992. Mismatch amplification mutation assay (MAMA): application to the c-H-ras gene. PCR Methods Appl. 2:14-20.

Dass, N. B., J. Hill, A. Muir, T. Testa, A. Wise, and G. J. Sanger. 2003. The rabbit motilin receptor: molecular characterization and pharmacology. Br. J. Pharmacol. 140:948-954.

DeClercq, P., I. Depoortere, M. Macielag, A. Vandermeers, M-C. Vandermeers-Piret, and T. L. Peeters. 1996. Isolation, sequence, and bioactivity of chicken motilin. Peptides 17:203-208.

Deniaud, E., J. Baguet, R. Chalard, B. Blanquier, L. Brinza, J. Meunier, M. C. Michallet, A. Laugraud, C. Ah-Soon, A. Wierinckx, M. Castellazzi, J. Lachuer, C. Gautier, J. Marvel, and Y. Leverrier. 2009. Overexpression of transcription factor Sp1 leads to gene expression perturbations and cell cycle inhibition. PLoS ONE 4:e7035.

Ensembl Genome Browser. 2004. European Bioinformatics Institute, UK. http://ensembl.genomics.org.cn/ Accessed June 2013.

Fang, M., Q. Nie, C. Luo, D. Zhang, and X. Zhang. 2010. Associations of GHSR gene polymorphisms with chicken growth and carcass traits. Mol. Biol. Rep. 37:423-428.

Feighner, S. D., C. P. Tan, K. K. McKee, O. C. Palyha, D. L. Hreniuk, S. S. Pong, C. P. Austin, D. Figueroa, D. MacNeil, M. A. Cascieri, R. Nargund, R. Bakshi, M. Abramovitz, R. Stocco, S. Kargman, G. O'Neill, L. H. Van Der Ploeg, J. Evans, A. A. Patchett, R. G. Smith, and A. D. Howard. 1999. Receptor for motilin identified in the human gastrointestinal system. Science 284:2184-2188.

Garthwaite, T. L. 1985. Peripheral motilin administration stimulates feeding in fasted rats. Peptides 6:41-44.

Han, R. L., Z. J. Lia, M. J. Lia, J. Q. Lib, X. Y. Lana, G. R. Sunb, X. T. Kangb, and H. Chena. 2011. Novel 9-bp indel in visfatin gene and its associations with chicken growth. Br. Poult. Sci. 52:52-57.

He, J., D. M. Irwin, R. Chen, and Y. P. Zhang. 2010. Stepwise loss of motilin and its specific receptor genes in rodents. J. Mol. Endocrinol. 44:37-44.

Howard, A. D., R. Wang, S. S. Pong, T. N. Mellin, A. Strack, X. M. Guan, Z. Zeng, D. L. Williams Jr., S. D. Feighner, C. N. Nunes, B. Murphy, J. N. Stair, H. Yu, Q. Jiang, M. K. Clements, C. P. Tan, K. K. McKee, D. L. Hreniuk, T. P. McDonald, K. R. Lynch, J. F. Evans, C. P. Austin, C. T. Caskey, L. H. Van der Ploeg, and Q. Liu. 2000. Identification of receptors for neuromedin $\mathrm{U}$ and its role in feeding. Nature 406:70-74.

Hu, Z. L., E. R. Fritz, and J. M. Reecy. 2007. AnimalQTLdb: a livestock QTL database tool set for positional QTL information mining and beyond. Nucl. Acids Res. 35:604-609.

In, K. H., K. Asano, D. Beier, J. Grobholz, P. W. Finn, E. K.
Silverman, E. S. Silverman, T. Collins, A. R. Fischer, T. P. Keith, K. Serino, S. W. Kim, G. T. De Sanctis, C. Yandava, A. Pillari, P. Rubin, J. Kemp, E. Israel, W. Busse, D. Ledford, J. J. Murray, A. Segal, D. Tinkleman, and J. M. Drazen. 1997. Naturally occurring mutations in the human 5-lipoxygenase gene promoter that modify transcription factor binding and reporter gene transcription. J. Clin. Invest. 99:1130-1137.

Kitazawa, T., H. Kaiya, and T. Taneike. 2007. Contractile effects of ghrelin-related peptides on the chicken gastrointestinal tract in vitro. Peptides 28:617-624.

Kitazawa, T., T. Taneike, and A. Ohga. 1997. Functional characterization of neural and smooth muscle motilin receptors in the chicken proventriculus and ileum. Regul. Pept. 71:87-95.

Kojima, M., H. Hosoda, Y. Date, M. Nakazato, H. Matsuo, and K. Kangawa. 1999. Ghrelin is a growth-hormone-releasing acylated peptide from stomach. Nature 402:656-660.

Lei, M., X. Peng, M. Zhou, C. Luo, Q. Nie, and X. Zhang. 2008. Polymorphisms of the IGF1R gene and their genetic effects on chicken early growth and carcass traits. BMC Genet. 9:70.

Lei, M. M., Q. H. Nie, X. Peng, D. X. Zhang, and X. Q. Zhang. 2005. Single nucleotide polymorphisms of the chicken insulinlike factor binding protein 2 gene associated with chicken growth and carcass traits. Poult. Sci. 84:1191-1198.

Leng, L., S. Wang, Z. Li, Q. Wang, and H. Li. 2009. A polymorphism in the 3 '-flanking region of insulin-like growth factor binding protein 2 gene associated with abdominal fat in chickens. Poult. Sci. 88:938-942.

Li, Z. H., H. Li, H. Zhang, S. Z. Wang, Q. G. Wang, and Y. X. Wang. 2006. Identification of a single nucleotide polymorphism of the insulin-like growth factor binding protein 2 gene and its association with growth and body composition traits in the chicken. J. Anim. Sci. 84:2902-2906.

Miegueu, P., K. Cianflone, D. Richard, and D. H. St-Pierre. 2011. Motilin stimulates preadipocyte proliferation and differentiation and adipocyte lipid storage. Am. J. Physiol. Endocrinol. Metab. 301: E758-766.

Neglia, S., N. Arcamone, V. Esposito, and G. Gargiulo. 2004. Ghrelin in the gastroenteric tract of birds: immunoreactivity expression. Vet. Res. Commun. 28:213-215.

Nie, Q., M. Fang, L. Xie, M. Zhou, Z. Liang, Z. Luo, G. Wang, W. Bi, C. Liang, W. Zhang, and X. Zhang. 2008. The PIT1 gene polymorphisms were associated with chicken growth traits. BMC Genet. 9:20.

Ohshiro, H., M. Nonaka, and K. Ichikawa. 2008. Molecular identification and characterization of the dog motilin receptor. Regul. Pept. 146:80-87.

Pérez-Enciso, M. and I. Misztal. 2004. Qxpak: a versatile mixed model application for genetical genomics and QTL analyses. Bioinformatics 20:2792-2798.

Poitras, P., P. Miller, D. Gagnon, and S. Stpierre. 1994. Motilin synthetic analogues and motilin receptor antagonists. Biochem. Biophys. Res. Commun. 205:449-454.

Qu, J. T., S. Q. Tang, D. X. Sun, and Y. Zhang. 2009. Polymorphisms of three neuroendocrine-correlated genes associated with growth and reproductive traits in the chicken. Poult. Sci. 88:722-727.

Rikimaru, K. and H. Takahashi. 2007. A method for discriminating a Japanese brand of chicken, the Hinai-jidori, using microsatellite markers. Poult. Sci. 86:1881-1886. 
Rikimaru, K., O. Sasaki, N. Koizumi, M. Komatsu, K. Suzuki, and H. Takahashi. 2011. Mapping of quantitative trait loci affecting growth traits in a Japanese native chicken cross. Asian-Aust. J. Anim. Sci. 24:1329-1334.

Rikimaru, K., M. Komatsu, K. Suzuki, Y. Uemoto, H. Takeda, and H. Takahashi. 2012. Association between cholecystokinin type A receptor haplotypes and growth traits in Japanese Hinai-dori crossbred chickens. Mol. Biol. Rep. 39:4479-4484.

Rikimaru, K., H. Takeda, Y. Uemoto, M. Komatsu, K. Takahasi, D. Suzuki, and H. Takahashi. 2013. Effect of a single-nucleotide polymorphism in the cholecystokinin type A receptor gene on growth traits in the Hinai-dori chicken breed. J. Poult. Sci. 50: 206-211.

Rosenfeld, D. J. and T. L. Garthwaite. 1987. Central administration of motilin stimulates feeding in rats. Physiol. Behav. 39:753-756.

Science Council of Japan. 2006. Guidelines for proper conduct of animal experiments. Tokyo, Japan.

Sigurdsson, S., H. H. Göring, G. Kristjansdottir, L. Milani, G. Nordmark, J. K. Sandling, M. L. Eloranta, D. Feng, N. Sangster-Guity, I. Gunnarsson, E. Svenungsson, G. Sturfelt, A. Jönsen, L. Truedsson, B. J. Barnes, G. Alm, L. Rönnblom, and A. C. Syvänen. 2008. Comprehensive evaluation of the genetic variants of interferon regulatory factor 5 (IRF5) reveals a novel 5 bp length polymorphism as strong risk factor for systemic lupus erythematosus. Hum. Mol. Genet. 17:872-881.

Song, C., X. Gu, C. Feng, Y. Wang, Y. Gao, X. Hu, and N. Li. 2011. Evaluation of SNPs in the chicken HMGA2 gene as markers for body weight gain. Anim. Genet. 42:333-336.

Song, J., H. Ugai, I. Kanazawa, K. Sun, and K. K. Yokoyama. 2001. Independent repression of a GC-rich housekeeping gene by Sp1 and MAZ involves the same cis-elements. J. Biol. Chem. 276:19897-19904.

Strausberg, R. L., E. A. Feingold, L. H. Grouse, J. G. Derge, R. D. Klausner, F. S. Collins, L. Wagner, C. M. Shenmen, G. D. Schuler, S. F. Altschul et al. 2002. Generation and initial analysis of more than 15,000 full-length human and mouse cDNA sequences. Proc. Natl. Acad. Sci. USA 99:16899-16903.

Tanaka, M., T. Miyazaki, I. Yamamoto, N Nakai, Y. Ohta, N. Tsushima, M. Wakita, and K. Shimada. 2003. Molecular characterization of chicken growth hormone secretagogue receptor gene. Gen. Comp. Endocrinol. 134:198-202.
UCSC Genome Browser Home. 2004. University of California, Santa Cruz, USA. http://genome.ucsc.edu Accessed June 2013.

Uemoto, Y., S. Sato, T. Ohtake, S. Sato, Y. Okumura, and E. Kobayashi. 2011. Ornithine decarboxylase gene is a positional candidate gene affecting growth and carcass traits in $F_{2}$ intercross chickens. Poult. Sci. 90:35-41.

Vincent, J-P., J. Mazella, and P. Kitabgi. 1999. Neurotensin and neurotensin receptors. Trends Pharmacol. Sci. 20:302-309.

$\mathrm{Xu}$, L., I. Depoortere, M. Tang, and T. L. Peeters. 2001. Identification and expression of the motilin precursor in the guinea pig. FEBS Lett. 490:7-10.

Xu, L., I. Depoortere, L. Thielemans, Z. Huang, M. Tang, and T. L. Peeters. 2003. Sequence, distribution and quantification of the motilin precursor in the cat. Peptides 24:1387-1395.

Yamamoto, I., H. Kaiya, C. Tsutsui, T. Sakai, A. Tsukada, M. Miyazato, and M. Tanaka. 2008. Primary structure, tissue distribution, and biological activity of chicken motilin receptor. Gen. Comp. Endocrinol. 156:509-514.

Zhang, H., S. H. Liu, Q. Zhang, Y. D. Zhang, S. Z. Wang, Q. G. Wang, Y. X. Wang, Z. Q. Tang, and H. Li. 2011. Fine-mapping of quantitative trait loci for body weight and bone traits and positional cloning of the $R B 1$ gene in chicken. J. Anim. Breed. Genet. 128:366-375.

Zhang, W., L. Zhao, T. R. Lin, B. Chai, Y. Fan, I. Gantz, and M. W. Mulholland. 2004. Inhibition of adipogenesis by ghrelin. Mol. Biol. Cell 15:2484-2491.

Zhang, Z. R., Y. P. Liu, Y. G. Yao, X. S. Jiang, H. R. Du, and Q. Zhu. 2009. Identification and association of the single nucleotide polymorphisms in calpain3 (CAPN3) gene with carcass traits in chickens. BMC Genet. 10:10.

Zhou, H., A. D. Mitchell, J. P. McMurtry, C. M. Ashwell, and S. J. Lamont. 2005. Insulin-like growth factor-I gene polymorphism associations with growth, body composition, skeleton integrity, and metabolic traits in chickens. Poult. Sci. 84:212-219.

Zigman, J.M., Y. Nakano, R. Coppari, N. Balthasar, J. N. Marcus, C. E. Lee, J. E. Jones, A. E. Deysher, A. R. Waxman, R. D. White, T. D. Williams, J. L. Lachey, R. J. Seeley, B. B. Lowell, and J. K. Elmquist. 2005. Mice lacking ghrelin receptors resist the development of diet-induced obesity. J. Clin. Invest. 115: 3564-3572. 